\title{
Do polyphenols enter the brain and does it matter? Some theoretical and practical considerations
}

\author{
Sebastian Schaffer • Barry Halliwell
}

Received: 13 September 2011/Accepted: 6 October 2011/Published online: 20 October 2011

(c) Springer-Verlag 2011

\begin{abstract}
Although several epidemiological and intervention studies suggest that polyphenols (PPs) and PP-rich foods may improve memory and cognition in animals and humans, PPs' mode of action is only poorly understood. To help distinguish between the different modes of action that have been proposed for PPs, it is obviously important to know how much PPs can accumulate in the brain, if any at all. However, reliable data on PP uptake into the brain of animals are limited as many studies failed to report important control procedures during data acquisition. In this paper, we summarize published data on the penetration of PPs into animal brain and review some hypotheses to explain the biological basis of potentially health-beneficial effects of PPs to the brain. Finally, we highlight promising new approaches, especially those of a hormetic doseresponse and gut microbiota-brain interaction, which may allow a better understanding of PPs' mode of action in animals and humans.
\end{abstract}

Keywords Antioxidants - Effective brain concentration · Gut microbiota $\cdot$ Hormesis · Metabolic signalling · Polyphenols · Plasma concentration $\cdot$ Residual blood . Vitamin C

S. Schaffer · B. Halliwell

Department of Biochemistry, Centre for Life Sciences, National University of Singapore, 22 Medical Drive, Singapore 117456, Singapore

S. Schaffer $\cdot$ B. Halliwell $(\bowtie)$

National University of Singapore, University Hall, Lee Kong Chian Wing, UHL \#05-02G, 21 Lower Kent Ridge Road, Singapore 119077, Singapore

e-mail: bchbh@nus.edu.sg

\section{Introduction}

Several epidemiological studies suggest that diets rich in polyphenols (PPs) beneficially affect human brain function (Commenges et al. 2000; Letenneur et al. 2007). Similarly, supplementing rodents and humans with isolated PPs (Macready et al. 2009; Maher et al. 2006) or PP-rich foods and plant extracts (e.g. tea, blueberries or pine bark extract) (Andres-Lacueva et al. 2005; Francis et al. 2006; Macready et al. 2009; Nurk et al. 2009; Ryan et al. 2008) may improve memory and cognition. Numerous mechanisms, such as free radical scavenging, metal chelation and the modulation of enzyme activities, have been proposed for explaining a positive impact of PPs on the brain (Schaffer et al. 2006; Spencer 2008, 2009). However, the existence of direct antioxidant or other significant systemic effects of PPs, especially in the brain, are often met with scepticism, mainly due to the relatively poor intestinal uptake of PPs, their substantial biotransformation (so that blood and tissue concentrations of unaltered PPs are very low) and rapid excretion (Halliwell et al. 2005; Halliwell 2007a, b; Hollman et al. 2011; Hu 2007; Lotito and Frei 2006; Zini et al. 2006).

From first principles, PPs might alter brain function at three locations: (1) outside the CNS (for instance by improving cerebral blood flow or by modulating signalling pathways from peripheral organs to the brain), (2) at the blood-brain barrier (BBB, e.g. by altering multi-drugresistant protein-dependent influx and efflux mechanisms of various biomolecules) and (3) inside the CNS (e.g. by directly modifying the activity of neurons and glial cells) (Ghosh and Scheepens 2009; Spencer 2007; Youdim et al. 2004). To help distinguish between these different modes of action, it is obviously important to know how much PPs can accumulate in the brain, if any at all. However, as many studies failed to report important control procedures, 
reliable data on PP uptake into the brain of animals are limited. For obtaining meaningful information on this question, data ideally need to be collected either in exsanguinated and perfused animals (or tissues) or, alternatively, corrected for residual blood in the brain (Youdim et al. 2004). The importance of accurate in vivo measurements of brain drug exposure is highlighted in a recent study conducted in rats by Friden et al. (2010) who developed a mathematical model correcting drug brain concentrations for residual blood. After applying their model, the authors noted that concentrations of the drugs indomethacin and moxalactam in rat brain were significantly influenced by the amount of drug present in the residual blood.

In this paper, we first discuss published data on the penetration of PPs into animal brain. In cases where the PPsupplemented animals have neither been perfused nor residual blood in the brain has been corrected for as potential confounder, a correction of the reported PP brain concentrations has been attempted based on the mathematical model published by Friden et al. (2010). The second part of the current article summarizes some of the prevailing hypotheses for explaining the biological basis of potentially health-beneficial effects of PPs to the brain. Finally, we highlight promising new approaches that may allow for better understanding PPs' mode of action in animals and humans.

\section{Concentration of polyphenols in brain and the effect of mathematical correction}

Since the mid-1990s, the number of articles published on PPs has increased exponentially. However, despite the tremendous interest in PP research, only a small fraction of all studies addressed the important question of PP uptake and bioavailability (Fig. 1). Unsurprisingly, our knowledge regarding PP absorption, metabolism, tissue distribution, intracellular accumulation and excretion is insufficient.

So far, PP brain bioavailability has mainly been studied in rodents although at least one study was conducted in higher organisms, i.e. pigs (Tables 1 and 2). Exsanguinated and perfused animals are the gold standard for determining the amount of nutrient or drug that penetrated into the brain. Data from studies following this approach indicate that PPs usually accumulate at levels below $1 \mathrm{nmol} / \mathrm{g}$ tissue (Section 1 of Table 2). Similar findings result from studies where the brain PP concentration has been corrected for residual blood (Section 2 of Table 2). Furthermore, Janle et al. (2010) used accelerator mass spectrometry for detecting small amounts of labelled PPs in brain of perfused rats. Apart from this, a substantial number of articles reported brain PP uptake and concentrations without

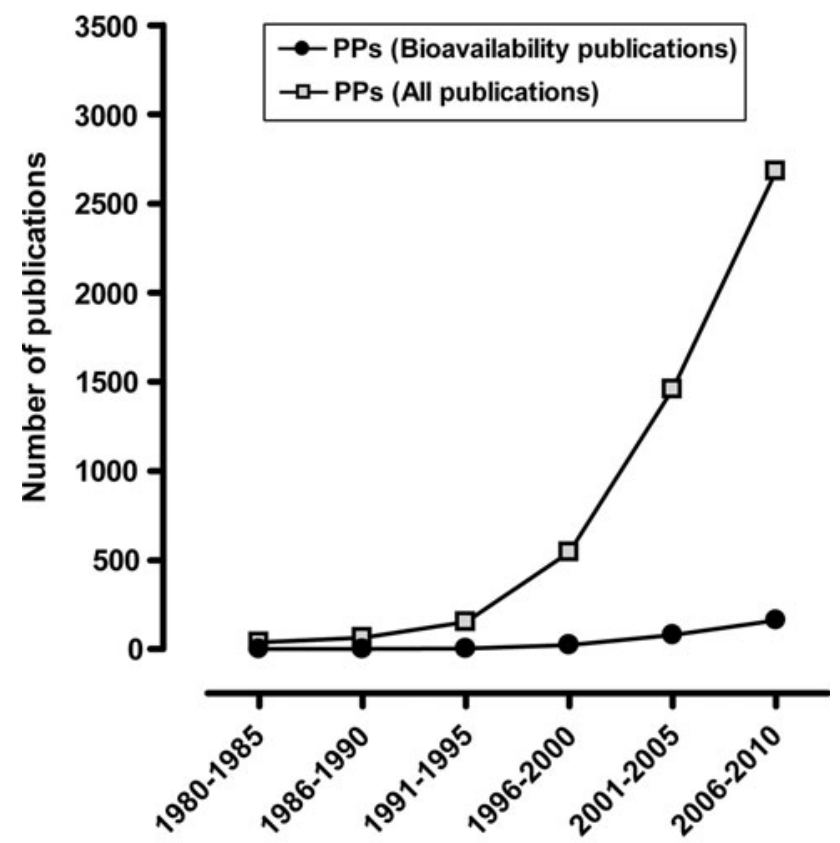

Fig. 1 Number of hits found for the search term 'polyphenols' or 'polyphenols AND bioavailability' in PubMed. The search field tag was limited to 'Title/Abstract'

considering residual blood as a potential confounder (Chang et al. 2000; Datla et al. 2001; Huebbe et al. 2010; Pan et al. 1999; Peng et al. 1998; Purkayastha et al. 2009).

In order to assess the magnitude of residual blood as a confounder in the quantification of brain PP concentrations, we applied a recently published mathematical correction model to one study, as an example (Friden et al. 2010). The limitation of this approach, however, is that studies only qualify for re-analysis when the mode of animal anaesthesia and killing ideally follow those published by Friden et al. (Table 3). In this case, the model can also be applied to other rodents, for example, mice (M. Friden, personal communication). The latter proposition is supported by a previous study reporting similar residual blood content (in per cent) for various rat and mouse organs (Schumann et al. 2007). Unfortunately, none of the studies on brain PP penetration available to us for evaluation strictly adhered to the above-mentioned criteria for re-analysis due to differences in the method of euthanasia and tissue sampling. However, as also mentioned by Friden et al. (2010), exsanguination by severing the heart seemed to result in less residual blood in rat brain compared to brain obtained from decapitated animals. Based on this notion, applying the correction model to studies where more residual blood in the brain samples will likely occur (as a result of the sampling procedure) can be considered conservative and will in most cases presumably still overestimate the amount of PP in the brain sample. Despite the above-mentioned 
Table 1 Methodological parameters of studies assessing PPs concentrations in animal brain (inclusion criteria were either the usage of exsanguinated and perfused animals or the correction for residual blood by other means)

\begin{tabular}{|c|c|c|c|c|c|c|c|c|c|}
\hline No. & PPs & Species & Route & Dosage & Duration & Sampling & Anaesthesia & $\begin{array}{l}\text { Killing and } \\
\text { tissue collection }\end{array}$ & References \\
\hline \multicolumn{10}{|c|}{ Section I: studies in exsanguinated and perfused animals } \\
\hline 1 & Epicatechin & Rat & Oral & $100 \mathrm{mg} / \mathrm{kg} \mathrm{BW}$ & 1 day & $\begin{array}{l}2 \mathrm{~h} \text { after } \mathrm{PP} \\
\text { intake }\end{array}$ & Phenobarbitone & $\begin{array}{l}\text { Plasma: } \\
\text { Decapitation } \\
\text { Brain: Perfusion }\end{array}$ & $\begin{array}{l}\text { Abd El } \\
\text { Mohsen } \\
\text { et al. } \\
\text { (2002) }\end{array}$ \\
\hline 2 & Pelargonidin & Rat & Oral & $50 \mathrm{mg} / \mathrm{kg} \mathrm{BW}$ & 1 day & $\begin{array}{l}2 \mathrm{~h} \text { and } 18 \mathrm{~h} \\
\text { after PP } \\
\text { intake }\end{array}$ & Pentobarbitone & Perfusion & $\begin{array}{l}\text { El Mohsen } \\
\text { et al. } \\
(2006)\end{array}$ \\
\hline 3 & $\begin{array}{l}\text { Grape seed } \\
\text { extract }\end{array}$ & Rat & Oral & $\begin{array}{l}300 \mathrm{mg} / \mathrm{kg} \mathrm{BW} \\
\text { (twice daily) }\end{array}$ & 3 days & $\begin{array}{l}4 \mathrm{~h} \text { after last } \mathrm{PP} \\
\text { intake }\end{array}$ & Isoflurane & $\begin{array}{l}\text { Cervical dislocation } \\
\text { and heart puncture } \\
\text { followed by } \\
\text { perfusion }\end{array}$ & $\begin{array}{l}\text { Prasain et al. } \\
(2009)\end{array}$ \\
\hline 4 & $\begin{array}{l}\text { Grape seed } \\
\text { extract }\end{array}$ & Rat & Oral & $\begin{array}{l}\text { Dose-escalating } \\
\text { design } \\
\text { Days 1-2: } \\
50 \mathrm{mg} / \mathrm{kg} \mathrm{BW} \\
\text { Days 3-4: } \\
100 \mathrm{mg} / \mathrm{kg} \mathrm{BW} \\
\text { Days } 5-10: \\
150 \mathrm{mg} / \mathrm{kg} \mathrm{BW}\end{array}$ & 10 days & $\begin{array}{l}8 \mathrm{~h} \text { after last } \\
\text { administration }\end{array}$ & - & $\begin{array}{l}\text { Plasma: Collected } \\
\text { from jugular vein } \\
\text { (catheter) } \\
\text { Brain: Perfusion }\end{array}$ & $\begin{array}{l}\text { Ferruzzi } \\
\text { et al. } \\
(2009)\end{array}$ \\
\hline 5 & $\begin{array}{l}\text { Blackberry } \\
\text { extract }\end{array}$ & Rat & Oral & $\begin{array}{l}15 \mathrm{~g} / \mathrm{kg} \text { diet } \\
\text { (with } \\
14.8 \mathrm{mmol} \\
\text { anthocyanins/ } \\
\mathrm{kg} \text { diet) }\end{array}$ & 15 days & $\begin{array}{l}3 \mathrm{~h} \text { after last } \\
\text { meal }\end{array}$ & Pentobarbital & $\begin{array}{l}\text { Blood: All blood } \\
\text { drawn from } \\
\text { abdominal aorta } \\
\text { Brain: removed } \\
\text { from bloodless } \\
\text { animals }\end{array}$ & $\begin{array}{l}\text { Talavera } \\
\text { et al. } \\
(2005)\end{array}$ \\
\hline 6 & $\begin{array}{l}\text { Epigallo } \\
\text { catechin- } \\
\text { 3-gallate }\end{array}$ & Rat & Oral & $500 \mathrm{mg} / \mathrm{kg} \mathrm{BW}$ & 1 day & $\begin{array}{l}1 \mathrm{~h} \text { after } \\
\text { administration }\end{array}$ & Ether & $\begin{array}{l}\text { Blood: Collected } \\
\text { from abdominal } \\
\text { artery } \\
\text { Brain: Perfusion }\end{array}$ & $\begin{array}{l}\text { Nakagawa } \\
\text { and } \\
\text { Miyazawa } \\
(1997)\end{array}$ \\
\hline 7 & Quercetin & Rat & Oral & $1 \% \mathrm{w} / \mathrm{w}$ & 1 month & $\begin{array}{l}\text { No details } \\
\text { given }\end{array}$ & Pentobarbital & $\begin{array}{l}\text { Blood: - } \\
\text { Brain: Perfusion }\end{array}$ & $\begin{array}{l}\text { Ishisaka } \\
\text { et al. } \\
\text { (2011) }\end{array}$ \\
\hline \multicolumn{10}{|c|}{ Section II: studies correcting for residual blood } \\
\hline 8 & Quercetin & Rat & Oral & $0.1 \%$ in diet & 11 weeks & $\begin{array}{l}\text { Morning w/out } \\
\text { overnight } \\
\text { fasting }\end{array}$ & Isoflurane & $\begin{array}{l}\text { Full bleeding from } \\
\text { aorta }\end{array}$ & $\begin{array}{l}\text { de Boer } \\
\text { et al. } \\
\text { (2005) }\end{array}$ \\
\hline 9 & Quercetin & Pig & Oral & $500 \mathrm{mg} / \mathrm{kg} \mathrm{BW}$ & 3 days & Fasting for $8 \mathrm{~h}$ & $\begin{array}{l}\text { No details } \\
\text { given }\end{array}$ & No details given & \\
\hline
\end{tabular}

$B W$ body weight

limitations, we suggest that our approach highlights the often underappreciated problem of confounded levels of PPs in brain tissue reported in the scientific literature.

In the study selected for re-assessment, female mice (6-7 weeks old) were fed a PP-poor, semi-synthetic diet supplemented with quercetin $(2 \mathrm{~g} / \mathrm{kg}$ diet $)$ for 6 weeks (Huebbe et al. 2010). The brain concentrations of quercetin and its metabolite, isorhamnetin, at baseline and at the end of the intervention for both control and supplemented animals are depicted in Fig. 2. The results of the mathematical correction model indicate that the actual amounts of brain quercetin and isorhamnetin in supplemented mice are about 8 and $27 \%$ lower, respectively, whereas values for control animals remained unchanged. Although only of moderate magnitude, the corrected values for brain PPs, especially of isorhamnetin, suggest that residual blood might confound supplementation studies aiming to quantify the enrichment of PPs in brain beyond baseline data. Somewhat surprising are the high baseline levels of quercetin in the brain of control animals 
Table 2 PPs concentrations in plasma and animal brain obtained from studies using either exsanguinated and perfused animals or correcting for residual blood by other means

\begin{tabular}{|c|c|c|c|c|c|}
\hline No. & PP measured & Plasma conc. & Correction achieved by & Brain conc. corrected & References \\
\hline \multicolumn{6}{|c|}{ Section I: studies in exsanguinated and perfused animals } \\
\hline 1 & $\begin{array}{l}\text { Epicatechin } \\
\text { metabolites (total) }\end{array}$ & $66 \mathrm{uM}$ & Perfusion & $\begin{array}{l}0.4 \mathrm{nmol} / \mathrm{g} \text { tissue } \\
\quad \text { (estimated) }\end{array}$ & $\begin{array}{l}\text { Abd El Mohsen et al. } \\
\text { (2002) }\end{array}$ \\
\hline \multirow[t]{2}{*}{2} & $\begin{array}{l}\text { Pelargonidin } \\
\text { metabolites (total) }\end{array}$ & $2 \mathrm{~h}: \sim 1.5 \mathrm{uM}$ & Perfusion & $\begin{array}{l}2 \mathrm{~h}: 0.16 \mathrm{nmol} / \mathrm{g} \\
\text { tissue }[43 \mathrm{ng} / \mathrm{g}]\end{array}$ & $\begin{array}{l}\text { El Mohsen et al. } \\
\text { (2006) }\end{array}$ \\
\hline & & \multicolumn{2}{|l|}{$18 \mathrm{~h}: \sim 0.65 \mathrm{uM}$} & \multicolumn{2}{|l|}{$18 \mathrm{~h}:<\mathrm{LOD}$} \\
\hline 3 & $(+)$-Catechin & $<\mathrm{LOD}$ & Perfusion & $53 \mathrm{ng} / \mathrm{g}$ tissue & Prasain et al. (2009) \\
\hline \multirow[t]{2}{*}{4} & Catechin & $1.98 \mathrm{ug} / \mathrm{ml}$ & \multirow[t]{2}{*}{ Perfusion } & $0.57 \mathrm{ng} / \mathrm{g}$ tissue & \multirow[t]{2}{*}{ Ferruzzi et al. (2009) } \\
\hline & Epicatechin & $3.86 \mathrm{ug} / \mathrm{ml}$ & & $0.29 \mathrm{ng} / \mathrm{g}$ tissue & \\
\hline 5 & $\begin{array}{l}\text { Cyanidin-3- } \\
\text { glucoside }\end{array}$ & $0.15 \mathrm{uM}$ & $\begin{array}{l}\text { Blood-less animals used; no explicit } \\
\text { information on brain perfusion }\end{array}$ & $0.21 \mathrm{nmol} / \mathrm{g}$ tissue & Talavera et al. (2005) \\
\hline 6 & $\begin{array}{l}\text { Epigallocatechin-3- } \\
\text { gallate }\end{array}$ & $12.3 \mathrm{uM}$ & Perfusion & $0.5 \mathrm{nmol} / \mathrm{g}$ tissue & $\begin{array}{l}\text { Nakagawa and } \\
\text { Miyazawa (1997) }\end{array}$ \\
\hline 7 & Quercetin & No details given & Perfusion & $40.1 \mathrm{pmol} / \mathrm{g}$ tissue & Ishisaka et al. (2011) \\
\hline \multicolumn{6}{|c|}{ Section II: studies correcting for residual blood } \\
\hline \multirow[t]{3}{*}{8} & Quercetin & $7.7 \mathrm{umol} / \mathrm{l}$ & \multirow[t]{3}{*}{ Hb method } & $<$ LOD & \multirow[t]{6}{*}{ de Boer et al. (2005) } \\
\hline & Isorhamnetin & $15.7 \mathrm{umol} / \mathrm{l}$ & & $0.19 \mathrm{nmol} / \mathrm{g}$ tissue & \\
\hline & Tamarixetin & $<\mathrm{LOD}$ & & $0.14 \mathrm{nmol} / \mathrm{g}$ tissue & \\
\hline \multirow[t]{3}{*}{9} & Quercetin & $1.1 \mathrm{umol} / \mathrm{l}$ & \multirow[t]{3}{*}{ Hb methods } & $0.22 \mathrm{nmol} / \mathrm{g}$ tissue & \\
\hline & Isorhamnetin & $0.15 \mathrm{umol} / \mathrm{l}$ & & $<\mathrm{LOD}$ & \\
\hline & Tamarixetin & $<\mathrm{LOD}$ & & $<$ LOD & \\
\hline
\end{tabular}

$L O D$ limit of detection

Table 3 Anaesthesia and tissue collection procedure prior analysis of brain drug concentrations and their mathematical correction as published in Friden et al. (2010)

\begin{tabular}{ll}
\hline Step & Procedure \\
\hline 1 & $\begin{array}{l}\text { Anaesthesia with isoflurane } \\
2\end{array}$ \\
$\begin{array}{c}\text { Collection of blood sample from abdominal aorta }(2 \mathrm{~mL}) \text { for } \\
\text { analysis }\end{array}$ \\
3 & $\begin{array}{l}\text { Exsanguination by severing the heart } \\
4\end{array}$ \\
\hline
\end{tabular}

despite the low quercetin concentrations $(0.12 \mu \mathrm{M})$ in blood. The authors provided two possible explanations for this observation: (1) the transfer of quercetin from the mothers to their offspring during the intrauterine development and (2) the uptake of quercetin (and its subsequent accumulation in the brain) from a standard feed (Huebbe et al. 2010). Although it is still difficult to say from current data whether some PPs not only accumulate but also persist (as the quercetin data for the control animals suggest) in specific target organs for longer periods of time, data published for other bioactive compounds, in particular the naturally occurring amino acid ergothioneine, are consistent with this notion (Cheah and Halliwell 2011).
Nonetheless, results from the aforementioned mouse study (Huebbe et al. 2010) in combination with those reports listed in Table 2 provide reasonable evidence that PPs do enter the brain at measurable levels. An additional important parameter affecting the correction for residual blood and subsequently the uptake of drug into brain is protein binding (Friden et al. 2010). For example, Diniz et al. (2008) observed significant, structure-dependent differences in the binding behaviours of PPs to plasma proteins, ranging from more than $90 \%$ human serum albumin (HSA) binding affinity for PPs such as apigenin and quercetin to below $10 \%$ as, e.g., in the case of epicatechin. Noteworthy, plasma fatty acids allosterically inhibit PP binding to HSA (Bolli et al. 2010), suggesting that dietary factors might modulate PP plasma, and subsequently, tissue distribution. The accuracy of PP quantification in brain, of course, also significantly depends on other parameters, such as PP extraction efficiency from the tissue as well as on the applied analytical method (Wilkinson et al. 2002).

\section{Does it matter that polyphenols can enter the brain?}

Classically, PPs are considered as potent antioxidants due to their ability to directly scavenge free radicals and other reactive species (RS, for details see Halliwell 2006) in vitro 


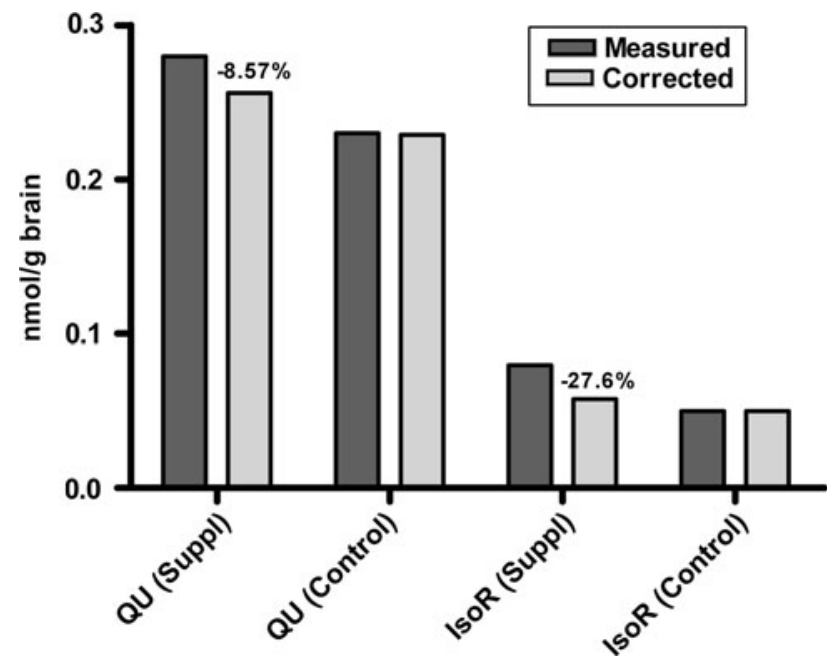

Fig. 2 Effect of mathematical correction for residual blood on the published concentrations of quercetin (OU) and isorhamnetin (IsoR) in the brain of quercetin-supplemented mice (Huebbe et al. 2010). For details see text

(Pannala et al. 1997; Russo et al. 2000; Visioli et al. 1998) and perhaps sometimes also in vivo. Given the brain's vulnerability to oxidative and nitrosative stress, the sufficient supply of the CNS with antioxidants is of prime importance (Halliwell 2006; Reiter 1995).

In the following, we compare the ability of PPs to act as brain antioxidants with ascorbic acid (AA, vitamin $\mathrm{C}$ ) one of the most abundant low-molecular-mass antioxidants in the mammalian brain (Rice 2000). AA levels of about 2,000 nmol/g tissue have been measured, for instance, in the brain of perfused, male Wistar rats (Sun et al. 1999). Some caution has to be taken when conducting vitamin $\mathrm{C}$ studies in rats and mice (both rodent species not only possess a much higher neuron density per $\mathrm{mm}^{3}$ than humans - and consequently greater AA content per $\mathrm{g}$ brain tissue - but are also able to synthesize their own vitamin $\mathrm{C}$, unlike humans who depend on a dietary AA supply). Nevertheless, rat brain AA levels are in a similar range to those reported for guinea pigs, which need vitamin $\mathrm{C}$ from the diet (about 1,500 nmol/g tissue; perfused animals Lykkesfeldt et al. 2007), but are (as expected) higher than in humans (about 600-900 nmol/g tissue) (Rice 2000; Terpstra et al. 2011). Compared to PPs (for details see Table 2), AA brain concentrations of perfused laboratory rodents are thus about 3,000-4,000 times higher, making it rather unlikely that PPs, even when considering their several fold higher in vitro antioxidant activity (RiceEvans et al. 1995; Schaffer et al. 2004), exert appreciable direct RS-scavenging effects in the mammalian brain, unless they act in different compartments, e.g. lipids, depending on their solubility in lipophilic and hydrophilic environments.
Furthermore, the question of whether compounds such as AA and PPs are active within the CNS also depends on their compartmentalization between the cerebrospinal fluid (CSF), extracellular fluid (ECF) and the different types of brain cells. Concentrations of AA are highest in neurons ( $\sim 10 \mathrm{mM})$, followed by glial cells $(\sim 1 \mathrm{mM}), \mathrm{CSF}$ $(\sim 500 \mu \mathrm{M})$ and ECF $(200-400 \mu \mathrm{M})$ (Rice 2000). Our knowledge of PP compartmentalization within the CNS, on the other hand, is rather scarce. Data from in vitro studies, however, might serve as a first approximation. First of all, there is now good evidence from cell culture experiments that PPs are able to enter at least some cell types (Ernst et al. 2010; Watjen et al. 2005), and in a few studies, actual PP uptake has been quantified (Table 4). Assuming an average cell volume of $22 \times 10^{-13} 1$ [=22 picolitres, based on cell volume data for HepG2 cells of $12.1 \times 10^{-13} 1$, PC12 cells of $20.5 \times 10^{-13} 1$ and cardiac myocytes of $33.4 \times 10^{-13} 1$ (Atkins et al. 1991; Leung et al. 1994; Wehner et al. 2002)], an estimated quercetin uptake of $20 \mathrm{nmol} / 10^{6}$ cells would result in an intracellular quercetin concentration of $9 \mathrm{mM}$. This, however, would require the extracellular presence of PPs at un-physiological concentrations of a few hundred micromolar (Table 4). As there is currently no evidence that CSF and ECF concentrations of PPs exceed 1-5 micromolar (at best), it is thus highly unlikely that intracellular PP concentrations in neurons and glial cells will exceed the very low micromolar to nanomolar range. This, clearly, is not sufficient for exerting any appreciable direct antioxidant effect (compared, e.g., to vitamin $\mathrm{C}$ and glutathione)_-but might still be high enough to modulate other cellular parameters in the CNS (see below).

Direct antioxidant effects of PPs are thus not very likely in the brain in vivo, nor are there any literature data we are aware of measuring accurate biomarkers of oxidative damage that show that PPs have direct antioxidant effects in the brain. We ought to consider the absence of evidence as evidence of absence for direct RS-scavenging activities of PPs in animals and humans, especially as PPs levels in vivo are likely too low to matter in the face of endogenous antioxidants (Halliwell and Gutteridge 2007).

How, then, can we explain the several studies reporting positive effects for PPs on brain function? One research field attracting more and more attention is the modulation of monoaminergic and GABA neurotransmission by PPs. The treatment of rats with PP-rich Ginkgo biloba extract for 14 days, for example, resulted in significantly increased extracellular levels of dopamine and noradrenaline (but not of serotonin) in the animals' prefrontal cortex (Yoshitake et al. 2010). Of the three main Ginkgo biloba extract constituents, the PP (flavonoid) fraction caused a significant (and most pronounced) increase in brain dopamine levels, whereas ginkgolides had only a moderate and 
Table 4 Cellular uptake of PPs reported for different cell lines

\begin{tabular}{|c|c|c|c|c|c|}
\hline PP & Test conc. $(\mu \mathrm{M})$ & Incubation time & Cell line & Intracellular conc. & Study \\
\hline Apigenin & 50 & $2 \mathrm{~h}$ & Caco-2 & $\sim 1.2 \mathrm{nmol} / \mathrm{mg}$ protein & Yokomizo and Moriwaki (2006) \\
\hline Kaempferol & & & & $\sim 1.8 \mathrm{nmol} / \mathrm{mg}$ protein & \\
\hline Luteolin & & & & $\sim 1.3 \mathrm{nmol} / \mathrm{mg}$ protein & \\
\hline Quercetin & & & & $\sim 0.9 \mathrm{nmol} / \mathrm{mg}$ protein & \\
\hline Myricetin & & & & ND & \\
\hline Myricetrin & & & & ND & \\
\hline Rutin & & & & ND & \\
\hline Isoquercitrin & & & & ND & \\
\hline Quercetin & 500 & $1 \mathrm{~h}$ & H4IIE & $33.4 \mathrm{nmol} / 10^{6}$ cells & Watjen et al. (2005) \\
\hline Fisetin & & & & $12.67 \mathrm{nmol} / 10^{6}$ cells & \\
\hline Myricetin & & & & $0.22 \mathrm{nmol} / 10^{6}$ cells & \\
\hline Morin & & & & $2.35 \mathrm{nmol} / 10^{6}$ cells & \\
\hline Taxifolin & & & & $0.2 \mathrm{nmol} / 10^{6}$ cells & \\
\hline Rutin & & & & 0 & \\
\hline Catechin & & & & 0 & \\
\hline $\mathrm{EC}$ & 50 & $1 \mathrm{~h}$ & Caco-2 & 0 & Vaidyanathan and Walle $(2003)^{\mathrm{a}}$ \\
\hline$(+)$-Catechin & & & & $\sim 150 \mathrm{pmol} / \mathrm{mg}$ protein & \\
\hline ECG & & & & $\sim 3,000 \mathrm{pmol} / \mathrm{mg}$ protein & \\
\hline EGCG & & & & $\sim 2,400 \mathrm{pmol} / \mathrm{mg}$ protein & \\
\hline Quercetin & 5 & $30 \mathrm{~min}$ & HepG2 & $\sim 900 \mathrm{pmol} / \mathrm{mg}$ protein & Boulton et al. (1999) ${ }^{\mathrm{a}}$ \\
\hline
\end{tabular}

$N D$ not detected

$P P$ polyphenols

a Data were estimated from graphs

bilobalides no effect (Yoshitake et al. 2010). The observed effects appear not to depend on the activity of monoamine oxidases (MAO-A and MAO-B) as these were unchanged in mice chronically treated with the extract (Fehske et al. 2009). The low concentration of PPs in brain (Table 2) compared to the $K_{i}$ values, for instance, of quercetin for MAO-A of $7.26 \mu \mathrm{M}$ and for MAO-B of $7.95 \mu \mathrm{M}$ (Dixon Clarke and Ramsay 2011) suggests that other parameters, such as neurotransmitter re-uptake mechanisms, might be involved in the modulation of monoaminergic neurotransmission by PPs (Fehske et al. 2009; Ofir et al. 2003). Mood and behavioural disorders often arise from a dysfunctional neurotransmission and thus might benefit from drug-induced alterations in the amount of available neurotransmitters within the CNS (Racagni and Popoli 2010). Neurotransmitter re-uptake inhibition in synaptosomal preparations has been reported for some PPs and PP-rich plant extract fractions (e.g. resveratrol, catechin or Ginkgo flavonoids) but not others (e.g. kaempferol) (Muller et al. 1998; Rocha et al. 2007; Yanez et al. 2006). Similarly, a plethora of in vitro data indicates that PPs act as modulators of the $\mathrm{GABA}_{\mathrm{A}}$-benzodiazepine receptor. Whereas the $K_{i}$ values for the affinity of many PPs to the receptor is in the one-digit to two-digit micromolar range, some PPs are effective at lower (and maybe physiologically achievable) concentrations, such as amentoflavone with reported $K_{i}$ values of 6-56 nM (Jager and Saaby 2011). Much more work, however, needs to be done in order to understand whether the same PP actions on $\mathrm{GABA}_{\mathrm{A}}$ receptors occur in vivo and, even more challenging, by what mechanism (Hanrahan et al. 2011; Jager and Saaby 2011).

Based on today's knowledge, other promising explanations of the possible brain effects of PPs are also indirect in nature: (1) the activation of a hormetic dose-response and (2) effects on peripheral systems of the body, which in turn influence CNS functioning.

Hormesis describes a process in which exposure to a low dose of an agent that is toxic at higher doses induces a beneficial effect on the cell or organism (Mattson and Cheng 2006). Whereas most studies describing hormetic effects for PPs have been performed in cell culture or the nematode C. elegans (Ali and Rattan 2006; Gruber et al. 2007; Pietsch et al. 2011; Wagner et al. 2011), recently, the first direct evidence for hormesis induction in vivo has been reported in mammals. Pretreatment of mice with the PP epicatechin significantly reduced the negative impact of stroke induction in wild-type but not Nrf2 knock-out animals (Shah et al. 2010). As the transcription factor Nrf2 is one of the key regulators responsible for the induction of antioxidant and cell protective genes, this study suggests 
that PPs might indeed operate by hormesis activation. One caveat affecting the evaluation of hormetic phenomena, however, needs to be considered based on ontogenetic studies, i.e. that a subject's developmental stage might influence the magnitude of an observed hormetic response. For example, the U-shaped effects of acute ethanol exposure on overall social activity of rats are not only influenced by the measuring time post-exposure but are also strongly age-dependent (Spear and Varlinskaya 2005). Similarly, changes in the penetration efficiency of substances due to the disruption of the blood-brain barrier, for example in stroke (Cipolla et al. 2004), might shift the dose-response away from reference values, posing either the risk of unexpected side effects or the possibility for an improved therapeutic outcome. Some authors also noted the lack of a precise definition of hormesis and furthermore pointed out that the evaluation of a hormetic response in terms of possible health effects must be carefully studied as compounds, even at low dose, might exert significant beneficial or detrimental effects on physiological and cellular mechanisms, which are often non-linear and chaotic in nature, such as coronary circulation, neuronal signalling or calcium oscillation (Chirumbolo 2011; Clay and Shrier 1999; Haberichter et al. 2001; Trzeciakowski and Chilian 2008). The perturbing impact of PPs at concentrations as low as $1 \mu \mathrm{M}$ on cellular signalling pathways and metabolic processes has been demonstrated, for example, for PP-dependent effects on mitochondrial calcium uptake and on the activity of protein kinase C (Kalfon et al. 2007; Montero et al. 2004). Note that there is currently a trend of moving away from studying PP parent compounds and towards the assessment of biological activities exerted by PP metabolites and degradation products. Several extensive reviews regarding the consequences of PPs and their metabolites on cellular mechanisms are available (Lau et al. 2005; Manach et al. 2004; Spencer et al. 2004, 2007; Visioli et al. 2011), although the overall picture remains somewhat diffuse given the impressive number of signalling pathways shown to be affected. Whereas little is known about the in vivo effects of PP metabolites and degradation products on the brain, evidence from some studies indicates that these compounds might also enter the CNS, although usually at a very low level (Abd El Mohsen et al. 2002; Ferruzzi et al. 2009; Huebbe et al. 2010).

However, many activities of PPs have, so far, only been demonstrated in cell culture studies, which are prone to artefacts (Halliwell 2003). Upon exposure to standard cell culture media (e.g. DMEM, MEM or RPMI), many PPs become degraded and, at the same time, initiate the production of hydrogen peroxide in the one-digit to threedigit micromolar range (Long et al. 2010; Schaffer and Halliwell 2011). Common medium supplements (such as pyruvate) or excreted cellular metabolites (for instance $\alpha$-ketoglutarate) effectively scavenge PP-derived hydrogen peroxide and thus become depleted, which can affect results where pyruvate or $\alpha$-ketoglutarate are important growth factors to the cells being cultured (Long and Halliwell 2009, 2011). Hence, careful thought is essential when elucidating the in vivo mode of PP action and subsequently their possible areas of preventive or therapeutic application in humans.

Furthermore, the regulation of brain integrity and function must not be seen in isolation but as strongly dependent on feedback information (in the form of hormones, nutrients, metabolites and, of course, sensory neuron signalling) of the body periphery. In addition, mainly physico-mechanical parameters, such as the amount of blood supplied to the brain, are important factors to consider when assessing CNS effects of patho-physiological events and preventive/therapeutic interventions (e.g. drugs and diet). Endothelial dysfunction, for example, is associated with reduced cerebral perfusion and the occurrence of dementia (Ghosh and Scheepens 2009). Reasonable evidence exists that PPs from cocoa (Francis et al. 2006; Heiss et al. 2007; Heiss et al. 2010) and other dietary sources, such as tea (Grassi et al. 2009) and grapes (Lekakis et al. 2005), increase blood flow in humans, thus possibly helping to provide the brain with greater amounts of oxygen and glucose. Negative studies, however, have also been published on this topic (Auclair et al. 2010; van Mierlo et al. 2010). A recurrent observation in many studies assessing the effect of bioactive compounds (PPs, phytochemicals and plant extracts) is the strong impact of age and health status on the study outcome. Several clinical trials indicate that young- to middle-aged healthy human subjects often do not benefit from the intake of bioactive compounds when applied in the form of antioxidant supplements or antioxidant-enriched foods (Boots et al. 2008; Canter and Ernst 2007; Kelly et al. 2008; Lee et al. 2009). Also, older humans suffering from advanced stages of chronic diseases (such as Alzheimer's disease) reveal negligible or zero therapeutic effects when the patients are treated with PPs or other phytochemicals (Daviglus et al. 2010; Lloret et al. 2009; Quinn et al. 2010). Thus, clearly more work is needed in order to identify the optimal time frame for preventive and therapeutic interventions in humans, probably not too young and not when disease has progressed to an advanced stage.

Another example highlighting the impact that peripheral organs can exert on brain (mal)function is metabolic signalling by the gastro-intestinal tract (GIT). Compared to blood, dietary PPs can be present in high amounts in the GIT and could even exert direct antioxidant effects there, e.g. in the stomach (Halliwell et al. 2000, 2005; Kanner and Lapidot 2001). Some PPs also reach the colon (Jenner et al. 2005; van Duynhoven et al. 2011). In the past 5-10 years, exciting new information regarding health implications of the 
brain-gut-enteric microbiota axis has emerged (Rhee et al. 2009). Whereas some aspects of this bidirectional interaction are well established, for instance the effect of mucosal inflammation on pain reception, effects of gut microbiota on other CNS-regulated phenomena such as mood changes or anxious behaviour have only recently been described (Forsythe et al. 2010; Rhee et al. 2009). A new study by Heijtz et al. (2011) emphasizes the importance of gut microbiota for brain development and behaviour. When comparing specific pathogen-free with germ-free mice, the authors found significant differences in motor control and anxiety-like behaviour between the two mouse groups, possibly indicating that evolution might have driven the link between gut microbiota and brain development. As PPs strongly affect both composition and metabolism of the intestinal microbiota, it is possible that this interaction might exert effects not only on the GIT but also indirectly on the brain, especially when considering that luminal microorganisms (about $10^{11}$ bacterial cells per gram colon content) represent 100 times the total genetic material contained in a human body, thus allowing for a stunning production of a wide range of metabolites (Forsythe et al. 2010; Rhee et al. 2009). Most of the biological activities that these microbial metabolites exert on the human body, and especially the brain, are currently unknown, but they might soon be revolutionizing how we look at human health and disease.

In conclusion, what does the scientific community need to do with respect to PP research? We propose two adjustments: (1) the development of more sophisticated analytical methods to establish levels of PPs and their metabolites to confirm the view that direct effects on brain cells and tissue are likely or unlikely and (2) a significant spike in non-reductionist research efforts for elucidating bi- and even multi-directional inter-organ actions and reactions, especially between peripheral organs and the brain, which are too often studied in isolation. Furthermore, in order to master the likely overwhelming amount of data associated with such complex research agendas, experimental research should ideally go hand-in-hand with systems biology (Assmus et al. 2006; Desiere 2004; Lemberger 2007). Only then, we predict, will the biomedical research community be able to significantly advance our understanding of the effects of PPs as external and internal determinants of human health and disease.

Acknowledgments $\mathrm{BH}$ is most grateful for the financial support provided by the Tan Chin Tuan Centennial Fund, Singapore.

\section{References}

Abd El Mohsen MM, Kuhnle G, Rechner AR et al (2002) Uptake and metabolism of epicatechin and its access to the brain after oral ingestion. Free Radic Biol Med 33:1693-1702
Ali RE, Rattan SI (2006) Curcumin's biphasic hormetic response on proteasome activity and heat-shock protein synthesis in human keratinocytes. Ann NY Acad Sci 1067:394-399

Andres-Lacueva C, Shukitt-Hale B, Galli RL et al (2005) Anthocyanins in aged blueberry-fed rats are found centrally and may enhance memory. Nutr Neurosci 8:111-120

Assmus HE, Herwig R, Cho KH et al (2006) Dynamics of biological systems: role of systems biology in medical research. Expert Rev Mol Diagn 6:891-902

Atkins DL, Rosenthal JK, Krumm PA et al (1991) Application of stereological analysis of cell volume to isolated myocytes in culture with and without adrenergic innervation. Anat Rec 231:209-217

Auclair S, Chironi G, Milenkovic D et al (2010) The regular consumption of a polyphenol-rich apple does not influence endothelial function: a randomised double-blind trial in hypercholesterolemic adults. Eur J Clin Nutr 64:1158-1165

Bolli A, Marino M, Rimbach G et al (2010) Flavonoid binding to human serum albumin. Biochem Biophys Res Commun 398:444-449

Boots AW, Wilms LC, Swennen EL et al (2008) In vitro and ex vivo anti-inflammatory activity of quercetin in healthy volunteers. Nutrition 24:703-710

Boulton DW, Walle UK, Walle T (1999) Fate of the flavonoid quercetin in human cell lines: chemical instability and metabolism. J Pharm Pharmacol 51:353-359

Canter PH, Ernst E (2007) Ginkgo biloba is not a smart drug: an updated systematic review of randomised clinical trials testing the nootropic effects of G. biloba extracts in healthy people. Hum Psychopharmacol 22:265-278

Chang HC, Churchwell MI, Delclos KB et al (2000) Mass spectrometric determination of Genistein tissue distribution in dietexposed Sprague-Dawley rats. J Nutr 130:1963-1970

Cheah IK, Halliwell B (2011) Ergothioneine: antioxidant potential, physiological function and role in disease. Biochim Biophys Acta. doi:10.1016/j.bbadis.2011.09.017

Chirumbolo S (2011) Hormesis, resveratrol and plant-derived polyphenols: some comments. Hum Exp Toxicol. doi:10.1177/ 0960327111408153

Cipolla MJ, Crete R, Vitullo L et al (2004) Transcellular transport as a mechanism of blood-brain barrier disruption during stroke. Front Biosci 9:777-785

Clay JR, Shrier A (1999) On the role of subthreshold dynamics in neuronal signaling. J Theor Biol 197:207-216

Commenges D, Scotet V, Renaud S et al (2000) Intake of flavonoids and risk of dementia. Eur J Epidemiol 16:357-363

Datla KP, Christidou M, Widmer WW et al (2001) Tissue distribution and neuroprotective effects of citrus flavonoid tangeretin in a rat model of Parkinson's disease. Neuroreport 12:3871-3875

Daviglus ML, Bell CC, Berrettini W et al (2010) NIH State-of-thescience conference statement: preventing Alzheimer's disease and cognitive decline. NIH Consens State Sci Statements 27

de Boer VC, Dihal AA, van der Woude H, Arts IC, Wolffram S, Alink GM, Rietjens IM, Keijer J, Hollman PC (2005) Tissue distribution of quercetin in rats and pigs. J Nutr 135:1718-1725

Desiere F (2004) Towards a systems biology understanding of human health: interplay between genotype, environment and nutrition. Biotechnol Annu Rev 10:51-84

Diniz A, Escuder-Gilabert L, Lopes NP et al (2008) Characterization of interactions between polyphenolic compounds and human serum proteins by capillary electrophoresis. Anal Bioanal Chem 391:625-632

Dixon Clarke SE, Ramsay RR (2011) Dietary inhibitors of monoamine oxidase A. J Neural Transm 118:1031-1041

El Mohsen MA, Marks J, Kuhnle G et al (2006) Absorption, tissue distribution and excretion of pelargonidin and its metabolites following oral administration to rats. Br J Nutr 95:51-58 
Ernst IM, Wagner AE, Lipinski S et al (2010) Cellular uptake, stability, visualization by 'Naturstoff reagent A', and multidrug resistance protein 1 gene-regulatory activity of cyanidin in human keratinocytes. Pharmacol Res 61:253-258

Fehske CJ, Leuner K, Muller WE (2009) Ginkgo biloba extract (EGb761) influences monoaminergic neurotransmission via inhibition of NE uptake, but not MAO activity after chronic treatment. Pharmacol Res 60:68-73

Ferruzzi MG, Lobo JK, Janle EM et al (2009) Bioavailability of gallic acid and catechins from grape seed polyphenol extract is improved by repeated dosing in rats: implications for treatment in Alzheimer's disease. J Alzheimers Dis 18:113-124

Forsythe P, Sudo N, Dinan T et al (2010) Mood and gut feelings. Brain Behav Immun 24:9-16

Francis ST, Head K, Morris PG et al (2006) The effect of flavanolrich cocoa on the fMRI response to a cognitive task in healthy young people. J Cardiovasc Pharmacol 47(Suppl 2):S215-20S215-S220

Friden M, Ljungqvist H, Middleton B et al (2010) Improved measurement of drug exposure in the brain using drug-specific correction for residual blood. J Cereb Blood Flow Metab 30:150-161

Ghosh D, Scheepens A (2009) Vascular action of polyphenols. Mol Nutr Food Res 53:322-331

Grassi D, Mulder TP, Draijer R et al (2009) Black tea consumption dose-dependently improves flow-mediated dilation in healthy males. J Hypertens 27:774-781

Gruber J, Tang SY, Halliwell B (2007) Evidence for a trade-off between survival and fitness caused by resveratrol treatment of Caenorhabditis elegans. Ann NY Acad Sci 1100:530-542

Haberichter T, Marhl M, Heinrich R (2001) Birhythmicity, trirhythmicity and chaos in bursting calcium oscillations. Biophys Chem 90:17-30

Halliwell B (2003) Oxidative stress in cell culture: an underappreciated problem? FEBS Lett 540:3-6

Halliwell B (2006) Oxidative stress and neurodegeneration: where are we now? J Neurochem 97:1634-1658

Halliwell B (2007a) Dietary polyphenols: good, bad, or indifferent for your health? Cardiovasc Res 73:341-347

Halliwell B (2007b) Flavonoids: a re-run of the carotenoids story? Novartis Found Symp 282:93-101 (discussion 101-4, 212-8:93101)

Halliwell B, Gutteridge J (2007) Free radicals in biology and medicine. Oxford University Press, Oxford

Halliwell B, Zhao K, Whiteman M (2000) The gastrointestinal tract: a major site of antioxidant action? Free Radic Res 33:819-830

Halliwell B, Rafter J, Jenner A (2005) Health promotion by flavonoids, tocopherols, tocotrienols, and other phenols: direct or indirect effects? Antioxidant or not? Am J Clin Nutr 81:268S$276 \mathrm{~S}$

Hanrahan JR, Chebib M, Johnston GA (2011) Flavonoid modulation of GABA(A) receptors. Br J Pharmacol 163:234-245

Heijtz RD, Wang S, Anuar F et al (2011) Normal gut microbiota modulates brain development and behavior. Proc Natl Acad Sci USA 108:3047-3052

Heiss C, Finis D, Kleinbongard P et al (2007) Sustained increase in flow-mediated dilation after daily intake of high-flavanol cocoa drink over 1 week. J Cardiovasc Pharmacol 49:74-80

Heiss C, Jahn S, Taylor M et al (2010) Improvement of endothelial function with dietary flavanols is associated with mobilization of circulating angiogenic cells in patients with coronary artery disease. J Am Coll Cardiol 56:218-224

Hollman PC, Cassidy A, Comte B et al (2011) The biological relevance of direct antioxidant effects of polyphenols for cardiovascular health in humans is not established. J Nutr 141:989S-1009S
$\mathrm{Hu}$ M (2007) Commentary: bioavailability of flavonoids and polyphenols: call to arms. Mol Pharm 4:803-806

Huebbe P, Wagner AE, Boesch-Saadatmandi C et al (2010) Effect of dietary quercetin on brain quercetin levels and the expression of antioxidant and Alzheimer's disease relevant genes in mice. Pharmacol Res 61:242-246

Ishisaka A, Ichikawa S, Sakakibara H et al (2011) Accumulation of orally administered quercetin in brain tissue and its antioxidative effects in rats. Free Radic Biol Med 51:1329-1336

Jager AK, Saaby L (2011) Flavonoids and the CNS. Molecules 16:1471-1485

Janle EM, Lila MA, Grannan M et al (2010) Pharmacokinetics and tissue distribution of $14 \mathrm{C}$-labeled grape polyphenols in the periphery and the central nervous system following oral administration. J Med Food 13:926-933

Jenner AM, Rafter J, Halliwell B (2005) Human fecal water content of phenolics: the extent of colonic exposure to aromatic compounds. Free Radic Biol Med 38:763-772

Kalfon L, Youdim MB, Mandel SA (2007) Green tea polyphenol (-)epigallocatechin-3-gallate promotes the rapid protein kinase $\mathrm{C}$ and proteasome-mediated degradation of Bad: implications for neuroprotection. J Neurochem 100:992-1002

Kanner J, Lapidot T (2001) The stomach as a bioreactor: dietary lipid peroxidation in the gastric fluid and the effects of plant-derived antioxidants. Free Radic Biol Med 31:1388-1395

Kelly RP, Poo YK, Isaac HB et al (2008) Lack of effect of acute oral ingestion of vitamin $\mathrm{C}$ on oxidative stress, arterial stiffness or blood pressure in healthy subjects. Free Radic Res 42:514-522

Lau FC, Shukitt-Hale B, Joseph JA (2005) The beneficial effects of fruit polyphenols on brain aging. Neurobiol Aging 26(Suppl 1): $128-132$

Lee CY, Isaac HB, Huang SH et al (2009) Limited antioxidant effect after consumption of a single dose of tomato sauce by young males, despite a rise in plasma lycopene. Free Radic Res 43:622-628

Lekakis J, Rallidis LS, Andreadou I et al (2005) Polyphenolic compounds from red grapes acutely improve endothelial function in patients with coronary heart disease. Eur J Cardiovasc Prev Rehabil 12:596-600

Lemberger T (2007) Systems biology in human health and disease. Mol Syst Biol 3:136

Letenneur L, Proust-Lima C, Le Gouge A et al (2007) Flavonoid intake and cognitive decline over a 10 -year period. Am J Epidemiol 165:1364-1371

Leung S, O’Donnell ME, Martinez A et al (1994) Regulation by nerve growth factor and protein phosphorylation of $\mathrm{Na} / \mathrm{K} / 2 \mathrm{Cl}$ cotransport and cell volume in PC12 cells. J Biol Chem 269:1058110589

Lloret A, Badia MC, Mora NJ et al (2009) Vitamin E paradox in Alzheimer's disease: it does not prevent loss of cognition and may even be detrimental. J Alzheimers Dis 17:143-149

Long LH, Halliwell B (2009) Artefacts in cell culture: pyruvate as a scavenger of hydrogen peroxide generated by ascorbate or epigallocatechin gallate in cell culture media. Biochem Biophys Res Commun 388:700-704

Long LH, Halliwell B (2011) Artefacts in cell culture: alphaKetoglutarate can scavenge hydrogen peroxide generated by ascorbate and epigallocatechin gallate in cell culture media. Biochem Biophys Res Commun 406:20-24

Long LH, Hoi A, Halliwell B (2010) Instability of, and generation of hydrogen peroxide by, phenolic compounds in cell culture media. Arch Biochem Biophys 501:162-169

Lotito SB, Frei B (2006) Consumption of flavonoid-rich foods and increased plasma antioxidant capacity in humans: cause, consequence, or epiphenomenon? Free Radic Biol Med 41:1727-1746

Lykkesfeldt J, Trueba GP, Poulsen HE et al (2007) Vitamin C deficiency in weanling guinea pigs: differential expression of 
oxidative stress and DNA repair in liver and brain. Br J Nutr 98:1116-1119

Macready AL, Kennedy OB, Ellis JA et al (2009) Flavonoids and cognitive function: a review of human randomized controlled trial studies and recommendations for future studies. Genes Nutr 4:227-242

Maher P, Akaishi T, Abe K (2006) Flavonoid fisetin promotes ERKdependent long-term potentiation and enhances memory. Proc Natl Acad Sci USA 103:16568-16573

Manach C, Scalbert A, Morand C et al (2004) Polyphenols: food sources and bioavailability. Am J Clin Nutr 79:727-747

Mattson MP, Cheng A (2006) Neurohormetic phytochemicals: lowdose toxins that induce adaptive neuronal stress responses. Trends Neurosci 29:632-639

Montero M, Lobaton CD, Hernandez-Sanmiguel E et al (2004) Direct activation of the mitochondrial calcium uniporter by natural plant flavonoids. Biochem J 384:19-24

Muller WE, Singer A, Wonnemann M et al (1998) Hyperforin represents the neurotransmitter reuptake inhibiting constituent of hypericum extract. Pharmacopsychiatry 31(Suppl 1):16-21

Nakagawa K, Miyazawa T (1997) Absorption and distribution of tea catechin, (-)-epigallocatechin-3-gallate, in the rat. J Nutr Sci Vitaminol (Tokyo) 43:679-684

Nurk E, Refsum H, Drevon CA et al (2009) Intake of flavonoid-rich wine, tea, and chocolate by elderly men and women is associated with better cognitive test performance. J Nutr 139:120-127

Ofir R, Tamir S, Khatib S et al (2003) Inhibition of serotonin reuptake by licorice constituents. J Mol Neurosci 20:135-140

Pan MH, Huang TM, Lin JK (1999) Biotransformation of curcumin through reduction and glucuronidation in mice. Drug Metab Dispos 27:486-494

Pannala AS, Rice-Evans CA, Halliwell B et al (1997) Inhibition of peroxynitrite-mediated tyrosine nitration by catechin polyphenols. Biochem Biophys Res Commun 232:164-168

Peng HW, Cheng FC, Huang YT et al (1998) Determination of naringenin and its glucuronide conjugate in rat plasma and brain tissue by high-performance liquid chromatography. J Chromatogr B Biomed Sci Appl 714:369-374

Pietsch K, Saul N, Chakrabarti S et al (2011) Hormetins, antioxidants and prooxidants: defining quercetin-, caffeic acid- and rosmarinic acid-mediated life extension in C. elegans. Biogerontology 12:329-347

Prasain JK, Peng N, Dai Y et al (2009) Liquid chromatography tandem mass spectrometry identification of proanthocyanidins in rat plasma after oral administration of grape seed extract. Phytomedicine 16:233-243

Purkayastha S, Berliner A, Fernando SS et al (2009) Curcumin blocks brain tumor formation. Brain Res 1266:130-138

Quinn JF, Raman R, Thomas RG et al (2010) Docosahexaenoic acid supplementation and cognitive decline in Alzheimer disease: a randomized trial. JAMA 304:1903-1911

Racagni G, Popoli M (2010) The pharmacological properties of antidepressants. Int Clin Psychopharmacol 25:117-131

Reiter RJ (1995) Oxidative processes and antioxidative defense mechanisms in the aging brain. FASEB J 9:526-533

Rhee SH, Pothoulakis C, Mayer EA (2009) Principles and clinical implications of the brain-gut-enteric microbiota axis. Nat Rev Gastroenterol Hepatol 6:306-314

Rice ME (2000) Ascorbate regulation and its neuroprotective role in the brain. Trends Neurosci 23:209-216

Rice-Evans CA, Miller NJ, Bolwell PG et al (1995) The relative antioxidant activities of plant-derived polyphenolic flavonoids. Free Radic Res 22:375-383

Rocha FF, Lima-Landman MT, Souccar C et al (2007) Antidepressant-like effect of Cecropia glazioui Sneth and its constituents- in vivo and in vitro characterization of the underlying mechanism. Phytomedicine 14:396-402

Russo A, Acquaviva R, Campisi A et al (2000) Bioflavonoids as antiradicals, antioxidants and DNA cleavage protectors. Cell Biol Toxicol 16:91-98

Ryan J, Croft K, Mori T et al (2008) An examination of the effects of the antioxidant pycnogenol on cognitive performance, serum lipid profile, endocrinological and oxidative stress biomarkers in an elderly population. J Psychopharmacol 22:553-562

Schaffer S, Halliwell B (2011) Comment on 'Hydroxytyrosol induces proliferation and cytoprotection against oxidative injury in vascular endothelial cells: role of Nrf2 activation and HO-1 induction'. J Agric Food Chem 59:10770-10771

Schaffer S, Eckert GP, Muller WE et al (2004) Hypochlorous acid scavenging properties of local Mediterranean plant foods. Lipids 39:1239-1247

Schaffer S, Eckert GP, Schmitt-Schillig S et al (2006) Plant foods and brain aging: a critical appraisal. Forum Nutr 59:86-115

Schumann K, Szegner B, Kohler B et al (2007) A method to assess $59 \mathrm{Fe}$ in residual tissue blood content in mice and its use to correct 59Fe-distribution kinetics accordingly. Toxicology 241:19-32

Shah ZA, Li RC, Ahmad AS et al (2010) The flavanol (-)epicatechin prevents stroke damage through the Nrf2/HO1 pathway. J Cereb Blood Flow Metab 30:1951-1961

Spear LP, Varlinskaya EI (2005) Low dose effects in psychopharmacology: ontogenetic considerations. Nonlinearity Biol Toxicol Med 3:97-111

Spencer JP (2007) The interactions of flavonoids within neuronal signalling pathways. Genes Nutr 2:257-273

Spencer JP (2008) Flavonoids: modulators of brain function. Br J Nutr 99(E Suppl 1):ES60-ES77

Spencer JP (2009) Flavonoids and brain health: multiple effects underpinned by common mechanisms. Genes Nutr 4:243-250

Spencer JP, Abd-el-Mohsen MM, Rice-Evans C (2004) Cellular uptake and metabolism of flavonoids and their metabolites: implications for their bioactivity. Arch Biochem Biophys 423:148-161

Sun F, Iwaguchi K, Shudo R et al (1999) Change in tissue concentrations of lipid hydroperoxides, vitamin $\mathrm{C}$ and vitamin $\mathrm{E}$ in rats with streptozotocin-induced diabetes. Clin Sci (Lond) 96:185-190

Talavera S, Felgines C, Texier $\mathrm{O}$ et al (2005) Anthocyanin metabolism in rats and their distribution to digestive area, kidney, and brain. J Agric Food Chem 53:3902-3908

Terpstra M, Torkelson C, Emir U et al (2011) Noninvasive quantification of human brain antioxidant concentrations after an intravenous bolus of vitamin C. NMR Biomed 24:521-528

Trzeciakowski J, Chilian WM (2008) Chaotic behavior of the coronary circulation. Med Biol Eng Comput 46:433-442

Vaidyanathan JB, Walle T (2003) Cellular uptake and efflux of the tea flavonoid (-)epicatechin-3-gallate in the human intestinal cell line Caco-2. J Pharmacol Exp Ther 307:745-752

van Duynhoven J, Vaughan EE, Jacobs DM et al (2011) Metabolic fate of polyphenols in the human superorganism. Proc Natl Acad Sci USA 108(Suppl 1):4531-4538

van Mierlo LA, Zock PL, van der Knaap HC et al (2010) Grape polyphenols do not affect vascular function in healthy men. J Nutr 140:1769-1773

Visioli F, Bellomo G, Galli C (1998) Free radical-scavenging properties of olive oil polyphenols. Biochem Biophys Res Commun 247:60-64

Visioli F, de la Lastra CA, Andres-Lacueva C et al (2011) Polyphenols and human health: a prospectus. Crit Rev Food Sci Nutr 51:524-546 
Wagner AE, Boesch-Saadatmandi C, Breckwoldt D et al (2011) Ascorbic acid partly antagonizes resveratrol mediated heme oxygenase-1 but not paraoxonase-1 induction in cultured hepatocytes-role of the redox-regulated transcription factor $\mathrm{Nrf} 2$. BMC Compl Altern Med 11:1

Watjen W, Michels G, Steffan B et al (2005) Low concentrations of flavonoids are protective in rat H4IIE cells whereas high concentrations cause DNA damage and apoptosis. J Nutr 135:525-531

Wehner F, Lawonn P, Tinel H (2002) Ionic mechanisms of regulatory volume increase (RVI) in the human hepatoma cell-line HepG2. Pflugers Arch 443:779-790

Wilkinson AP, Wahala K, Williamson G (2002) Identification and quantification of polyphenol phytoestrogens in foods and human biological fluids. J Chromatogr B Analyt Technol Biomed Life Sci 777:93-109

Yanez M, Fraiz N, Cano E et al (2006) Inhibitory effects of cis- and trans-resveratrol on noradrenaline and 5-hydroxytryptamine uptake and on monoamine oxidase activity. Biochem Biophys Res Commun 344:688-695

Yokomizo A, Moriwaki M (2006) Effects of uptake of flavonoids on oxidative stress induced by hydrogen peroxide in human intestinal Caco-2 cells. Biosci Biotechnol Biochem 70:1317-1324

Yoshitake T, Yoshitake S, Kehr J (2010) The Ginkgo biloba extract $\mathrm{EGb} 761(\mathrm{R})$ and its main constituent flavonoids and ginkgolides increase extracellular dopamine levels in the rat prefrontal cortex. Br J Pharmacol 159:659-668

Youdim KA, Shukitt-Hale B, Joseph JA (2004) Flavonoids and the brain: interactions at the blood-brain barrier and their physiological effects on the central nervous system. Free Radic Biol Med 37:1683-1693

Zini A, Del Rio D, Stewart AJ et al (2006) Do flavan-3-ols from green tea reach the human brain? Nutr Neurosci 9:57-61 